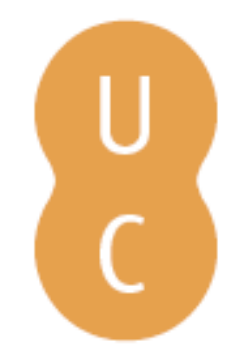

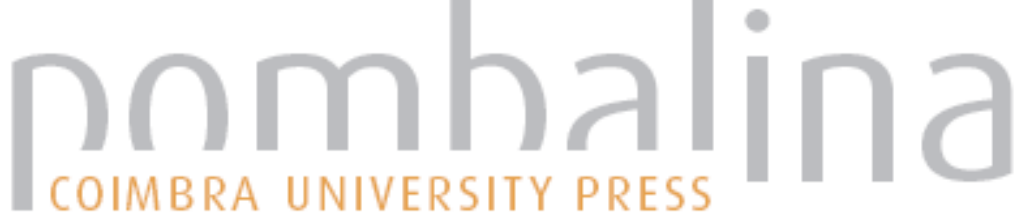

\section{Identity and Cosmopolitism: the Jewish Politeuma of Alexandria}
Autor(es):
Leão, Delfim F.
Edições Afrontamento; CITCEM - Centro de Investigação Clássicos e Humanísticos; Alexandria University; Imprensa da Universidade de Coimbra
Publicado por: Transdisciplinar «Cultura, Espaço e Memória»; Centro de Estudos
persistente:
DOI:
URI:http://hdl.handle.net/10316.2/36165
Accessed : $\quad$ 26-Apr-2023 09:50:18
DOI:http://dx.doi.org/10.14195/978-989-26-0966-9_8

A navegação consulta e descarregamento dos títulos inseridos nas Bibliotecas Digitais UC Digitalis, UC Pombalina e UC Impactum, pressupõem a aceitação plena e sem reservas dos Termos e Condições de Uso destas Bibliotecas Digitais, disponíveis em https://digitalis.uc.pt/pt-pt/termos.

Conforme exposto nos referidos Termos e Condições de Uso, o descarregamento de títulos de acesso restrito requer uma licença válida de autorização devendo o utilizador aceder ao(s) documento(s) a partir de um endereço de IP da instituição detentora da supramencionada licença.

Ao utilizador é apenas permitido o descarregamento para uso pessoal, pelo que o emprego do(s) título(s) descarregado(s) para outro fim, designadamente comercial, carece de autorização do respetivo autor ou editor da obra.

Na medida em que todas as obras da UC Digitalis se encontram protegidas pelo Código do Direito de Autor e Direitos Conexos e demais legislação aplicável, toda a cópia, parcial ou total, deste documento, nos casos em que é legalmente admitida, deverá conter ou fazer-se acompanhar por este aviso.

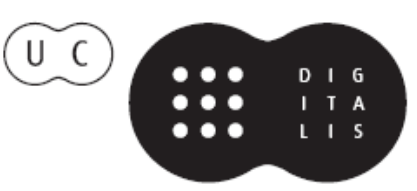




\title{
IDENTITY AND COSMOPOLITISM: \\ THE JEWISH POLITEUMA OF ALEXANDRIA
}

\author{
DELFIM F. LEÃO
}

University of Coimbra. Centro de Estudos Clássicos e Humanísticos (University of Coimbra).

\begin{abstract}
Taking into account the well-known process of ethnic, cultural and linguistic fusion which constitutes the basis for the huge development of the city of Alexandria (and is in itself an impressive legacy of Alexander's empire), it becomes important to understand up to what point would it be possible for a certain group to safeguard a distinctive identity - at a cultural, religious, and political level - within a space deeply marked by cosmopolitism and by the confluence of different sensibilities. The Macedonian and Greek communities, which were closer to the governing elite, would find a suitable formula of orienting their behaviour by using rules that derived from a common political and cultural identity - the so-called concept of politikoi nomoi. The Jewish community, which was as well important in the city, managed also to obtain, according to literary tradition, significant advantages from Alexander and the Ptolemies, especially the right to «live according to their ancestral laws». In this process of identitarian affirmation, a determinant role must had been played by the translation of the Torah by the Septuaginta, because it enabled the sacred text with the possibility of reaching a position comparable to the Greek nomoi, thus contributing to the establishment of a legal koine, which, even without ceasing to respect royal authority, would be central in daily life and in dealing with private conflicts.
\end{abstract}




\section{FROM ALEXANDER TO ALEXANDRIA}

Any discussion about Alexandria cannot avoid a reference, even if short, to the charismatic personality that launched the bases for the foundation of a city, which, like its mentor and creator, would embody the spirit of an entire period ${ }^{1}$. In fact, although Alexander was still in his early thirties when he died (356-323), he managed to conquer, in only a few years, an impressive empire. His brilliant military skills together with an outstanding political sagacity elevated him, still in life, to the heights of deification, and this process of legendary amplification was continued by later writers and historians, as well as by popular tradition, thus making it more difficult to distinguish between historical factuality and mere ideological exploitation in what respects his personality and deeds. Actually, Alexander marked not only the end of a cycle, but he also created the conditions that would lead the ancient world to the Hellenistic epoch. Politically, this period was less exposed to unbalances and changes than were the Archaic and Classical ages. Part of the explanation may reside in the fact the Hellenistic Period was characterized by the domain over vast territories with a huge population, thus suffering less the pernicious effects of frontier struggles and of an excessive divisionism. At any rate, the main reason is to be found in the centralization of political (and often also economic) power in the hands of the monarch, on whom depended the whole administrative structure, which constituted anyway one of the most remarkable aspects of this period, resulting from the combination of the monarchic Macedonian experience with a long lasting Asiatic and Egyptian tradition. Moreover, even if from a cultural and linguistic perspective the Greek matrix (clearly preferred by the ruling elite) dominates the Hellenistic Period, it cannot be understood without other cultural and ethnic influxes, whose fusion will result in the existence of a civilization which was «common» (koine) and transversal to the «inhabited world» (oikoumene) - in a clear rupture with the traditional opposition between Greeks and Barbarians, which until then dominated Greece and the way the non-Greek «otherness» was seen².

At any rate, even if it is certain that the role played by Alexander was determinant to start this revolution of the ancient world, the crystallization of the main traits of the Hellenistic society would occur only during the time of the Diadochi - the generals that served under his orders and involved themselves in struggle after Alexander's death, in a dispute

\footnotetext{
${ }^{1}$ On the foundation of Alexandria, see SILVA, in this same volume, supra. All the dates mentioned along this paper are prior to the Christian era. I would like to express my gratitude to Nuno Simões Rodrigues, for suggestions and helpful criticism concerning an earlier version of this paper, although he cannot be held responsible for the final perspectives here expressed. ${ }^{2}$ This cosmopolitism characteristic of the biggest Hellenistic cities will increase a lot the mobility of ideas, persons and goods. Thereby, the formation of a list of «wonders» or of «things that caused admiration» (thaumata) cannot be dissociated from the conscience that there were «things deserving to be admired» (theamata) in distant lands, which were nevertheless a part of that «globalized» world visited by curious travellers, avid of new sensations. On this, see CLAYTON; PRICE, 1988: 4-5; on the specific case of the lighthouse from Alexandria, see LEÃO; MANTAS, 2009, a work which inspires some of the observations made in this part of the analysis.
} 
that would last for several decades. The inevitable fragmentation of Alexander's former empire originated the kingdoms of Egypt, Macedonia, Asia, and later that of Pergamum also, which, from a political perspective, were organized as hereditary monarchies. Although the position of the king met variants in what concerned the way his sovereignty was exerted, it is undeniable that this kind of political regime had turned into a historical necessity, because only a strong and stable centralized power could keep the cohesion of vast territories, with many ethnic, cultural and geographic differences.

In what respects the global space of Hellas, most of the former poleis continued to exist along the Hellenistic age, at least as urban spaces, although without the autonomy and liberty of movements of which they had enjoyed during the Archaic and Classic Periods, especially in terms of external policy. Because the essence of the Hellenistic state depended on the person of the monarch and on the group of collaborators directly working with him, the structure of the polis ended up by being a strange body within this new reality. Even though, it could not simply be eliminated, because of the symbolic importance it had in the past history of Greece. The poleis managed thereby to keep the same constitutional apparatus of the past (popular assembly, council, courts, annually elected magistrates), but were now dependent on the will of the king, whose orders had to be obeyed, whether transmitted by letter, by royal regulation (diagramma) or by royal ordinance (prostagma). Formally, the image of autonomy was therefore kept, as long as there was also the preoccupation of moulding the decrees of the polis according to the instructions of the monarch, which were thus turned into binding law ${ }^{3}$. Up to a certain point, this situation constituted a fiction tacitly accepted by both parties, because both could extract benefits from it.

Another feature distinctive of the Hellenistic Period and of the strategy adopted by Alexander was the founding of new cities, sometimes with a demographic concentration that would be unthinkable to the classic poleis. The most emblematic of those new establishments was certainly Alexandria, a city that would substitute Memphis as the capital of reign of Egypt, under the Ptolemies ${ }^{4}$. This dynasty was initiated by Ptolemy, a distinguished general under Alexander and one of the firsts to understand how unrealistic was the project of trying simply to replace the former emperor by another person. Instead of that, he chose to reinforce the stability of the reign of Egypt, an objective that went in accord with the preoccupation of legitimating his power as sovereign, because, besides the military power, Ptolemy had no other secure basis to validate that domain. Accordingly the connection to

\footnotetext{
${ }^{3}$ At any rate, the payment of a tribute and the acceptance of the presence of royal garrisons, among other charges supported by each individual polis, were an unequivocal sign of their dependence towards the power of the sovereign. On this question, see LEÃO, 2009a: 170-173.

${ }^{4}$ In Antiquity, were founded almost twenty cities with the name Alexandria (cf. Stephanus of Byzantium, s.v. a Alexandreiai). The one under analysis, however, built according to a plan of Deinocrates of Rhodes, in the Nile Delta, would become the most important of them all, to the point of this period being also frequently named after it. For a collection of the sources dealing with the cities founded by Alexander, see HECKEL; YARDLEY, 2004: 303-310.
} 
Alexander and to the idea of success associated with the emperor would meet in perfection that desideratum. One of the first signs of this strategy may be found in the fact that Ptolemy literally abducted the body of Alexander, when it passed by Egypt in the way from Babylonia to Macedonia. The corpse started by being kept in Memphis, but when the capital was moved to Alexandria, it followed the same destination and was finally placed in a golden sarcophagus ${ }^{5}$.

Identical motivation may explain, at least in part, the erection of the two most emblematic monuments of the new capital: the Museum (or shrine to the Muses) and the Library ${ }^{6}$. Although the details concerning its construction are scanty and subject to many doubts, it is usually accepted that the decision to build them was made by Ptolemy I Soter, and that his son (Ptolemy II Philadelphus) undertook the noble task of expanding them. Both the Museum and the Library represent, already in Antiquity, a vivid illustration of the cosmopolitan spirit of the new Hellenistic cities. Their creation has also been understood as an expression of the Peripatetic influx over this golden period for the science, but it also matches a long lasting tradition of cultural sponsorship, deeply rooted already in the tyrannies of the Archaic and Classical Periods, which the new monarchs intended to cultivate as well ${ }^{7}$. Besides that, in the case of the Ptolemies those monuments contributed moreover, as stated before, to the objective of reinforcing the connection with Alexander and of legitimating the domain of a Greek matrix (and thereby foreigner) in a cultural context as exuberant as that of the ancient Egypt.

Despite the importance of those emblematic constructions, the city of Alexandria constituted also a notable ethnic mosaic, where three communities were particularly important: the indigenous Egyptians, the Macedonians and Greeks in general (culturally and politically dominants), and the Jews. Even if it is correct to state that the authority of the pharaoh worked as a centripetal force, fundamental to keep the whole bulk together, there was nevertheless a high risk of disaggregation (or at least of conflict), especially on the part of those who were more passionate in keeping their religious and cultural roots, as happened with the Jews. It is thereby the aim of this paper to discuss, in the next section, the way the cosmopolitism characteristic of the Hellenistic Period (and of Alexandria in particular) managed to deal with the demands of a strong and deeply rooted identitarian consciousness.

\section{THE JEWISH POLITEUMA OF ALEXANDRIA}

The notice of contacts between the Greek world and the Jews goes back to a very distant time in the past, as can be inferred from Hebrew names (as Japheth and Javan) remi-

\footnotetext{
${ }^{5}$ Later substituted by a coffin in glass. On the strategy adopted by Ptolemy to legitimate his power, see ERSKINE, 1995.

${ }^{6}$ On this question, see the analysis made by Maria Helena da Rocha Pereira, in this same volume, infra.

${ }^{7}$ See PARKER, 1998; LEÃO, 2009b: 518-519.
} 
niscent of Greek mythical names (Iapetos and Ion), and from the fact that king David himself employed, in a period as distant as the 10th century, Greek mercenaries from Crete. On the other side, remains of pottery found in Samaria suggest the existence of commercial contacts with Greece already in the 8th century. The traditional Athenian emblem of the owl was discovered in Jewish coins minted in the 5th century and, during the Persian invasion, Jewish mercenaries were among the Persian troops that invaded Greece, in 480, under the orders of Xerxes ${ }^{8}$. One of the earliest significant allusions to the Jews, in Greek literature, occurs in a short reference in the Histories of Herodotus (2.104.2-3), concerning the circumcision, a practice that the Syrians of Palestine (i.e. the Jews) had adopted from the Egyptians ${ }^{9}$.

According to Josephus (Against Apion, 1.176-182), Clearchus of Soli, a former pupil of Aristotle, related in his first book On Sleep that the master had had a meeting with a Jew in Asia Minor. The story is usually considered to be apocryphal, but the fact that the Peripatetic Clearchus found the notice worth of record is an indicator of the high opinion hold on the Jews (as well as on the Indians) as a people inclined to the philosophical reasoning. An approach identically positive is made by Theophrastus, who succeeded Aristotle as the head of the Lyceum and whose testimony (quoted by Porphyry, On Abstinence, 2.26) has the undeniable merit of being the earliest source, outside the Bible, to describe the Jewish sacrifices ${ }^{10}$. Among those earliest accounts on Jews made by non-Jews, the largest testimony derives from the work History of Egypt written by Hecataeus of Abdera, in a long passage quoted by Diodorus of Sicily (Historical Library, 40.3). Even if it has some mistakes (as stating that Moses had founded Jerusalem and established the sacred Temple) and manifests some criticism towards the zealous character of the Jews, as a social characteristic deriving from the harsh experience of exile, Hecataeus presents nonetheless a quite positive image of the Jews ${ }^{11}$, with whom he might have been in direct contact by the time he visited Egypt.

With the reference to Hecataeus of Abdera (who lived ca. 360-290), one arrives into a period comprised between the campaigns of Alexander and the beginnings of the dynasty of the Ptolemies, an epoch that shall open a new and gleaming chapter in the history of Jews, especially in what concerns their establishment in Egypt. Josephus (Against Apion, 1.186-204) ascribes to this same Hecataeus a treaty On the Jews, but its author is, most

\footnotetext{
${ }^{8}$ Cf. Flavius Josephus, Against Apion, 1.172-173, who derives this information from a Greek poet named Choerilus. See FELDMAN, REINHOLD, 1996.

${ }^{9}$ For other parallelisms between the Semitic world and Greek literature, from the Homeric Poems down to Xenophon, see the detailed systematization of RODRIGUES, 2005.

${ }^{10}$ Even if he also registers several mistakes, like stating that sacrifices were made during the night or that humans were used as sacrificial victims.

${ }^{11}$ Cf. 40.3.4: «as a result of their own expulsion [from Egypt, Moses] introduced an intolerant mode of life, hostile to foreigners».
} 
probably, a Jew that might have composed this work around the middle of the 2nd century ${ }^{12}$. Despite those limitations, one of the passages of Pseudo-Hecataeus quoted by Josephus is quite illustrative of the importance attributed to the respect of traditional regulations among Jews - a feature that Alexander was wise enough to respect, similarly to what he did with other conquered populations, like the Persians. It is thereby pertinent to evoke this episode as an introduction to the question of the privileges that might have been received by the Jews who decided to move to Alexandria:

Then Hecataeus indicates in turn our attitude toward the laws (nomoi), that we choose to suffer anything rather than transgress them, and consider this to be noble. For this reason, he says, though they are verbally abused by their neighbors and by all those who arrive from abroad, as well as being insolently treated on a regular basis by the Persian kings and satraps, they cannot be shifted from their conviction; on the contrary, defenseless they face on behalf of these both tortures and the most terrible of all deaths rather than deny their ancestral ways (ta patria). He also provides several evidences of this strong-mindedness in relation to the laws (nomoi). He says that when Alexander was on one occasion in Babylon and had decided to clear the temple of Bel which had collapsed, he ordered all his soldiers alike to transport the soil; only the Judeans did not comply, but endured severe beating and paid heavy fines, until the king pardoned them and granted them an amnesty ${ }^{13}$.

The presence of Jewish troops serving under Alexander is not surprising, because, as discussed before, already in the 5th century it was possible to find mercenaries with that same origin among the Persian army ${ }^{14}$. On the other side, the idea that the Macedonian leader might have shown understanding towards the interdictions dictated by Jewish laws (even facing the risk of some loss of authority ${ }^{15}$ ) finds a possible parallel in the way Alexander knew how to respect former enemies, either because he was convinced that this was the best way of acting or by mere political pragmatism. In fact, after having conquered Persia, he decided to adopt some aspects of the Persian protocol, even when he had to face the incomprehension of his fellow Macedonians ${ }^{16}$. Thus, despite not being wholly improbable

\footnotetext{
${ }^{12}$ For more details on the «discovery» of the Jews by Greek authors, see FELDMAN; REINHOLD, 1996: 1-14, esp. 10, in what respects the case of the Pseudo-Hecataeus now under analysis.

${ }^{13}$ Josephus, Against Apion, 1.190-192. Translated by MASON, 2007: 110-112. The Greek words transliterated between brackets are my addition. The same is valuable to other passages quoted in translation throughout the paper.

${ }^{14}$ HENGEL, 1989: 187 and n. 1, says that there is no reason to doubt that Jewish mercenaries served under Alexander, although he considers unhistorical the tradition stating that the Macedonian monarch gave isopoliteia (equal civic rights) to the Judean militaries that decided to establish in Alexandria.

${ }^{15}$ MASON, 2007: 112 n. 650, comments that the punishment of those disobeying soldiers «seems unnaturally light».

${ }^{16}$ It is particularly meaningful the ritual of proskynesis («prostration»), which Alexander started to demand as a sign of respect towards himself, but was interpreted by many of his companions as an indication of growing megalomania. On the way Alexander's behaviour evolved from the image of a leader of a pan-Hellenic colligation against the Barbarians into a strategy of favouring the inclusion of the defeated into the new budding order, see LEÃO, 2005.
} 
from a historical perspective, this detail reinforces a series of many others transmitted by tradition, which tended to present Alexander as a great benefactor of Judean identity.

The sources go to the point of suggesting that this support may have been influenced by divine intervention. In fact, tradition states that the first visit of Alexander to Jerusalem (in 332) was preceded by moments of great tension, because the high priest had decided, in a first moment, to remain faithful to Darius, a choice that led the Macedonians to march against Jerusalem. The vivid memory of this episode was preserved in Josephus' Jewish Antiquities (11.304-346), in terms whose historicity is, to say the least, highly suspect. Actually, the epiphany of Alexander in Jerusalem has too many points of contact with another experience of divine inspiration - a fact that cannot be ruled out as simple coincidence lived during the first part of the year 331: the famous pilgrimage of the Macedonian king to the sanctuary of Amon, in the oasis of Siwah (Libya), undertaken in a time when he had already chosen the place where the new capital of Egypt should be established ${ }^{17}$. Several details adduced when Alexander visits the temple of Jerusalem - like bringing the Book of Daniel before him (a book which was in reality written only around 164), where the prediction was made that a Greek would overcome the Persian empire - strongly suggest that the episode reflects probably a later Jewish tradition, where are detected the same signs of legendary amplification in what respects the deeds of the Macedonian leader. Nonetheless, it is still pertinent for the objectives of this analysis to evoke the final part of the narrative, where are mentioned the putative privileges granted by Alexander to the Jews:

And, when the Book of Daniel was shown to him, in which he had declared that one of the Greeks would destroy the empire of the Persians, he believed himself to be the one indicated; and in his joy he dismissed the multitude for the time being, but on the following day he summoned them again and told them to ask for any gifts which they might desire. When the high priest asked that they might observe their country's laws (patrioi nomoi) and in the seventh year be exempt from tribute, he granted all this. Then they begged that he would permit the Jews in Babylon and Media also to have their own laws (idioi nomoi), and he gladly promised to do as they asked. And, when he said to the people that if any wished to join his army while still adhering to the customs of their country (ethe patria), he was ready to take them, many eagerly accepted service with him ${ }^{18}$.

Leaving aside the question of the highly suspect historicity of this report, which moves back to the time of Alexander decisions that were, in fact, taken much later ${ }^{19}$, the essence of

\footnotetext{
${ }^{17}$ For an analysis of Josephus' report, by comparing aspects of the expedition to Jerusalem with the visit to the sanctuary of Amon, see MODRZEJEWSKI, 1995: 50-55.

${ }^{18}$ Josephus, Jewish Antiquities, 11.337-339. The translation is taken from MARCUS, 1958: 477-479.

${ }^{19}$ MODRZEJEWSKI, 1995: 55, says that Josephus is simply «anticipating by some 130 years the step actually taken by Antiochus III about 200 B.C., when he established the status of Jerusalem in the Seleucid empire».
} 
the political and ideological meaning of the measures here mentioned may nevertheless be valid. In reality, from a political perspective, this report shows that Judea was able to keep, throughout the Hellenistic Period, a position comparable to the one it had during the Persian domination: the capacity to act as a ethnic and religious entity, organized around the priesthood power, whose centre was the sacred Temple at Jerusalem. From an ideological viewpoint, the account illustrates the bases for the interrelations that were to be established between the Hellenistic sovereigns and the Jews: the first would distribute benefits and accept to respect the Mosaic law, while the latter would guarantee fidelity to the monarch and the readiness to fight under his command. There was however an important evolution concerning the inner legal nature of the Torah: in the past, it worked for the Jews as a law issued by the central power, binding by itself; but now it was presented as the «ancestral law» (patrios nomos) of the Jews, whose validity had to be confirmed by the new rulers. This way the Torah ended up by becoming closer to the juridical statute of the patrioi nomoi used by the Greeks of the Asian cities freed by Alexander from the Persian yoke. This possible parallelism between the legal situation of the Jews and that of the Greeks is a question that demands further inquiry, taking as reference the Jewish politeuma of Alexandria, which represents an elucidative example of the way the Jews from the Diaspora could organize themselves into stable communities, from a social, political and legal standpoint.

According to Pseudo-Hecataeus ${ }^{20}$, not long after the battle of Gaza (312), the group of Jews who came to Egypt following the Macedonian conquest brought with them the Torah. Ezekias, the high priest who accompanied them from Judaea, gathered a group of friends, possibly during the Sabbath, and read them the whole text, in Hebrew. Still according to Pseudo-Hecataeus, "he had their settlement (katoikesis) and the constitution written (politeia gegrammene) $»^{21}$. The passage is awkward and ambivalent, because the context does not make clear whether the terms katoikesis and politeia should be understood as being applied to the past history of the Jews or to the very moment when this group established in Alexandria ${ }^{22}$. Independent from the way this passage is interpreted, it remains a fact that the Jewish community felt very soon the need of having a Greek translation of the Torah, due perhaps to the circumstance that the process of Hellenization had been so quick that, a few decades after their establishment in Alexandria, most of the Jews were no longer able to

\footnotetext{
${ }^{20}$ Quoted by Josephus, Against Apion 1.186-189.

${ }^{21}$ Josephus, Against Apion, 1.189. Translated by MASON, 2007: 110.

${ }^{22}$ HENGEL, 1989: 192-193, is also ambivalent in the way he interprets this politeia gegrammene, which he tends to identify with a royal decree allowing the Jews to establish in Alexandria with a special statute of ethnic minority. HEGERMANN, 1989: 160 , states that the passage expressly mentions «a short royal decree, the contents of which would be comparable to the letter from Antiochus III to Zeuxis». However, the suggestion that the text was read from the (Hebrew) original may imply, on the contrary, that it was the Torah and that the politeia in question was the constitution of the Judean nation. On the other hand, the idea that Ezekias «had been closely in touch with us» (synethes hemin genomenos) may be an indication that the high priest was acquainted with the Greeks and with their habits. On the interpretation of this crooked passage and on its connection to the translation of the Septuaginta, see also MODRZEJEWSKI, 1995: 99-104; MASON, 2007: 110, n. 636.
} 
understand the Hebrew. The first version of the Torah to Greek is the famous translation by the Septuaginta, and this is not the time to discuss thoroughly in what conditions it may have been put into practice. For the purposes of this work it is enough to recall two possible explanations for the making of the translation: first, the aforementioned hypothesis that it was motivated by the insufficient linguistic proficiency in Hebrew of the Jews attending the Synagogue in Alexandria; second, the tradition that it was the successor of Ptolemy I Soter (therefore Ptolemy II Philadelphus) who, around the year 270, had decided to have the Torah translated into Greek, in order to enrich the collections of the Library ${ }^{23}$. According to the same tradition, Demetrius of Phalerum, a former Athenian statesman, was assigned the role of supervising the task ${ }^{24}$. It is not implausible that both reasons may have played a complementary role, and therefore that a practical need of the Jewish community had met the monarch's desire to improve the capacity of the Library (thus widening the access to a text to which part of his subjects attributed a capital importance).

This tradition is, in fact, recorded in a document known as the Letter of Aristeas, supposedly written by a courtier, but whose author is most probably a Jew. According to this testimony, the Jewish community and the king himself were so satisfied with the work of the translators that they decided that it should be considered a paradigmatic text and remain unchanged in the future. For the purposes of this analysis, and despite the great importance of the exegetic questions raised by the Bible of the Septuaginta, it is the reaction of the Jews and the way the Jewish community is represented that has a more direct interest. Let us evoke then a paraphrase of the Letter of Aristeas provided by Josephus:

Now, when the Law (nomos) had been transcribed and the work of translation brought to an end in seventy-two days, Demetrius assembled all the Jews at the same place where the laws (nomoi) had been rendered, and in the presence of the translators read them aloud. Thereupon the people expressed their approval of the elders who had interpreted the Law (nomos), and also praised Demetrius for conceiving the idea through which he had become the originator of great benefits to them, and they urged him as well to give their leaders the Law (nomos) to read; and all of them, including the priest and the eldest of the translators and the chief officers (proestekotes) of the community (politeuma), requested that, since the translation had been so successfully completed, it should remain as it was and not be altered ${ }^{25}$.

From a political and legal standpoint, this text provides some precious information. The juridical nature of the Torah is insistently underlined by the terms used in Greek to

\footnotetext{
${ }^{23}$ See FELDMAN, REINHOLD, 1996: 17-22, esp. 18-19.

${ }^{24}$ As is remarked by MODRZEJEWSKI, 1995: 100, this attribution to Demetrius is rather awkward, because he «had been unwise enough to favor the succession of the king's eldest son in preference to Philadelphus», falling into disgrace when Philadelphus was made king.

${ }^{25}$ Jewish Antiquities, 12.107-108. Translation by MARCUS, 1957: 53-55.
} 
mention it (nomos/nomoi); on the other side, the Jewish community is given the name politeuma. In the above mentioned passage of Pseudo-Hecataeus on the coming of Ezekias to Alexandria, it was the word katoikesis that had been used, a term that, together with the variant katoikia, is the one generally employed to define a colony of outsiders in a particular site $^{26}$. This kind of organizations implied some capacity of self-government, but not necessarily the civic rights characteristic of a city ${ }^{27}$. Politeuma is a word that may also be used to name generically any urban settlement and its inhabitants, although it classifies more in particular a community of alien settlers (even if not specifically Jews), with privileges up to a certain point comparable to civic rights. Another distinctive aspect that deserves being mentioned is that those ethnic groups are regularly characterized by the fact of having as well a strong religious identity.

In order to establish politeumata and katoikiai it would be certainly necessary to have an official authorization. Maybe the above mentioned politeia gegrammene in the passage of Pseudo-Hecataeus about Ezekias could have corresponded to this foundational document, despite the difficulties concerning the interpretation of this expression. On the other side, even if the tradition of the benefits granted by Alexander to the Jews is certainly magnified and at least in part anachronistic, it may nevertheless reflect the essence of the conditions given to the first Jewish settlers of Alexandria ${ }^{28}$ : the right of living according to their ancestral laws or customs (patrioi nomoi, idioi nomoi, ethe patria) and of applying those same traditional laws among the persons who voluntarily consider them as binding rules as long as they did not enter in conflict with the royal authority. Even without including among these concessions the right of full citizenship (as happened with the Greek and Macedonian communities), this was undoubtedly an intelligent way of promoting mobility and attracting active populations. It also favoured social peace, because politeumata like the one existing in Alexandria had the legal capacity of appointing magistrates and of creating their own grid of courts and schools, where the norms of the Mosaic Law could be applied and taught ${ }^{29}$. This reality is, in fact, clearly underlined by another passage in Josephus:

\footnotetext{
${ }^{26}$ On the terminology used in the sources to refer to those relatively autonomous communities, see HEGERMANN, 1989: 158-161, whose arguments are adopted at this point. On the use of the term politeuma in political theorization since the time of Aristotle and Isocrates, but with particular incidence throughout the Hellenistic Period, see GAMBETTI, 2009: 43-52. The same author states (p. 48-49) that the Jewish politeuma of Alexandria was certainly military in origin, and that this circumstance may have granted its members a distinct and superior status by comparison to the rest of the Jewish community, which constituted the plethos of Alexandria in broad sense.

${ }^{27}$ Nevertheless sometimes the politeumata could develop into cities. There were other designations to name communities of aliens, like laos, synodos and synagoge (although the last two are later in time).

${ }^{28}$ See supra commentary on Josephus, Jewish Antiquities, 11.337-339.

${ }^{29}$ HEGERMANN, 1989: 161, accepts that some Jewish colonists may have acquired, as a personal reward, the status of full citizenship, but he sustains (as most scholars also do) that the Jews as a community never got that right. In the future, this situation would be the cause of enormous tensions with the Greek community, as happened when, already in Roman times, Augustus decided to apply taxes to all non-citizens. He would reduce as well the rights of the Jewish politeuma of Alexandria. On this, see RODRIGUES, 2007a: 337.
} 
In Egypt, for example, territory has been set apart for a Jewish settlement (katoikia), and in Alexandria a great part of the city (polis) has been allocated to this nation (ethnos). And an ethnarch (ethnarches) of their own has been installed, who governs the people (ethnos) and adjudicates suits (kriseis) and supervises contracts (symbolaia) and ordinances (prostagmata), just as if he were the head (archon) of a sovereign state (politeia autoteles $)^{30}$.

Therefore, the governing structure was initially almost monarchic, but maybe it did not last long, because the paraphrase of the Letter of Aristeas, previously discussed, refers to a group of «chief officers (proestekotes) of the community (politeuma)», and not to a single person who concentrated in himself all the authority. It is also not improbable that the governing organic of the politeuma may had been suffering a growing Greek influence, as happened with the language and with some more practical procedures, like those involving for example Jewish litigants and Greek judges ${ }^{31}$. In reality and although after having followed a very different path, the Greeks of Alexandria and of other Hellenistic cities had reached a group of regulations understood as «common laws» or «civic laws» (politikoi nomoi), which remitted not to an archetypical text (as happened with the Jewish Torah), but to a tradition common to several poleis, which formed a juridical structure globally identified with the Greek legal experience. The recognition of the binding validity of those traditional determinations (which fell into the broad concept of patrioi nomoi) ended up by being one of the most efficient solutions found by the Ptolemies to attract to Egypt many aliens and to stimulate the mobility without putting at risk the social peace and the authority of the monarch. In effect, the several Egyptian, Greek and Jewish nomoi, to which legal validity was granted, had to be harmonized with the authority of the monarch, who had the ultimate word in the administration of justice, through his regulations (diagrammata) and ordinances (prostagmata). But just as the politikoi nomoi provided the Greek community with the juridical framework necessary to the political organization and to the resolution of conflicts, so did the Torah in what respects the Jewish politeuma - and this is why the work of the Septuaginta became so crucial. As time went by and as a natural result of this confluence of multiple political traditions, it should be expected the emergence of a common legal substrate, comparable in its origins and objectives to the process verified in other domains characteristic of this period. Thereby, just as it happened with the linguistic and cultural koine, the Hellenistic age (and especially Alexandria) favoured also the development of a legal koine, responsible as well for the success of the Ptolemies ${ }^{32}$. It was thus found

\footnotetext{
${ }^{30}$ Jewish Antiquities, 14.117. Translation by MARCUS, 1957: 509.

${ }^{31}$ This is the situation of a certain Dositheos, a Jew of Egyptian origin, who had sued a Jewish woman; their case was judged by a group of Greek magistrates, in a court of Crocodilopolis. On this case, see MODRZEJEWSKI, 1995: 108-109.

${ }^{32}$ On the characteristics of this legal koine, see MODRZEJEWSKI, 1995: 107-112.
} 
an acute procedure of harmonizing the cosmopolitism originated by the new political and social reality with the necessity to keep a strong identitarian matrix; it was thereby secured a space for the affirmation of the individual, in an universe marked by the unifying confluence of multiple sensibilities. 